SILVEIRA, BS; TORRES, JLR; ORIOLI JÚNIOR, V; FAVARO, JHS; COSTA, LL; CHARLO, HCO. 2021. Cover crops in the production of green and sweet corn. Horticultura Brasileira 39: 094-0101. DOI: http://dx.doi.org/10.1590/s0102-0536-20210114

\title{
Cover crops in the production of green and sweet corn
}

\section{Bruna de S Silveira ${ }^{1} \mathbb{D}$; José Luiz R Torres ${ }^{1} \mathbb{D}$; Valdeci Orioli Júnior ${ }^{1} \mathbb{D}$; João Henrique de S Favaro ${ }^{1} \mathbb{D}$; Luciene L Costa ${ }^{1} \mathbb{D}$; Hamilton César de $O$ Charlo $^{1} \mathbb{D}$}

${ }^{1}$ Instituto Federal do Triângulo Mineiro (IFTM), Uberaba-MG, Brasil; brunasilveira@iftm.edu.br; jlrtorres@iftm.edu.br (author for correspondence); valdeci@iftm.edu.br; joaofvr9@gmail.com; luciene@iftm.edu.br; hamiltoncharlo@iftm.edu.br

\begin{abstract}
Intensive conventional tillage cultivation of both green and sweet corn can contribute to soil degradation when compared to no-till systems. This study aimed to assess the agronomic characteristics and physicochemical quality of green and sweet corn grains grown under succession planting using different cover crops. Two experiments were conducted, one with green corn and the other sweet corn, using a randomized block design consisting of seven treatments: brachiaria (B); Pearl millet (PM); showy crotalaria (SC); $\mathrm{SC}+\mathrm{B}$; $\mathrm{PM}+\mathrm{B} ; \mathrm{PM}+\mathrm{SC}$ and $\mathrm{PM}+\mathrm{SC}+\mathrm{B}$, with four repetitions. The fresh $(\mathrm{FW})$ and dry weight (DW) of the cover crops and decomposition of their residue were assessed, in addition to the agronomic performance and bromatological quality of green and sweet corn grains. Brachiaria showed the lowest FW and DW production, highest residue decomposition rate and shortest half-life when compared to the other soil covers assessed. Productivity and yield for sweet corn grains and green corn ears were not statistically affected by the different cover crop residues. The cover crop residues influenced moisture content, total titratable acidity and total soluble solids in green corn, and lipids, proteins, total soluble solids, $\mathrm{pH}$ and ascorbic acid in sweet corn.
\end{abstract}

Keywords: Zea mays, specialty corn, plant residues, productivity, physicochemical characteristics.

\section{RESUMO}

\section{Plantas de cobertura na produção de milho verde e doce}

O cultivo intensivo de forma convencional, tanto do milho verde quanto do milho doce pode contribuir para a degradação do solo, quando comparado aos cultivos em sistemas de plantio direto. $\mathrm{O}$ objetivo deste estudo foi avaliar as características agronômicas e a qualidade físico-química dos grãos de milho verde e doce, cultivados em sucessão a diferentes coberturas do solo. Foram instalados dois experimentos, um com milho verde e outro com milho doce, no delineamento experimental de blocos casualizados, com quatro repetições e sete tratamentos: braquiária $(\mathrm{B})$; milheto $(\mathrm{M})$; crotalária (C); $\mathrm{C}+\mathrm{B} ; \mathrm{M}+\mathrm{B} ; \mathrm{M}+\mathrm{C}$ e $\mathrm{M}+\mathrm{C}+\mathrm{B}$, com quatro repetições. Avaliouse a produção de massa verde (MV) e seca (MS) das coberturas e a decomposição dos seus resíduos, o desempenho agronômico e a qualidade bromatológica dos grãos dos milhos verde e doce. Observou-se que a braquiária foi a cobertura que apresentou a menor produção de MV e MS, maior taxa de decomposição dos resíduos e menor tempo de meia vida, quando comparada as outras coberturas avaliadas. A produtividade e o rendimento do grão no milho doce e espiga no milho verde não foram afetados estatisticamente pelos resíduos das diferentes coberturas verde que antecederam seus cultivos. Os resíduos vegetais das diferentes coberturas afetaram a umidade, acidez total titulável e sólidos solúveis totais no milho verde. No milho doce afetaram os lipídeos, proteínas, sólidos solúveis totais, potencial hidrogeniônico e ácido ascórbico.

Palavras-chave: Zea mays, milhos especiais, resíduos vegetais, produtividade, características físico-químicas.

Received on May 12, 2020; accepted on November 7, 2020

$\mathrm{C}$ orn (Zea mays) is grown throughout the year in all Brazilian states and has contributed to the country's ranking as the second largest producer and exporter of the crop worldwide (Conab, 2019).

So-called specialty corn varieties (popcorn, green, sweet and baby corn) derive from a common ancestor and are gaining ground among Brazilian growers because they attract different markets when compared to common maize. It can also be consumed fresh or industrially processed (Souza et al., 2013).

Green and sweet corn are harvested at approximately 90 days after planting date (DAP) in summer and 100 DAP in winter, at 70 to $80 \%$ moisture content, before the sugars are fully converted into starch, and are therefore considered vegetables (Luz et al., 2014). At this stage, green corn contains approximately $3 \%$ sugar and 60 to $70 \%$ starch and sweet corn 9 to $14 \%$ sugar and 30 to $35 \%$ starch, with protein content varying from 6 to $12 \%$ in both varieties (Pereira Filho et al., 2018).

These specialty corn varieties are grown year-round under intensive conventional tillage systems, causing soil degradation. However, the introduction of no-till practices in regions where these crops are cultivated can contribute to sustainable production (Horvathy Neto et al., 2014). In addition, 
to improve the physical quality of soil, plant residues left on the surface improve soil fertility and biological activity (Torres et al., 2019).

High nutrient cycling of these residues has contributed to maintain or increase yield in common (Assis et al., 2013; Collier et al., 2018) and specialty corn crops (Pedrotti et al., 2015; Oliveira et al., 2017; Miranda et al. 2020).

The yield of green and sweet corn as well as concentrations of sugar, starch, protein, lipids and other components of specialty corn varieties can vary according to the production factors and management system used. In brassica crops, Torres et al. (2017) found that plants used as soil cover influenced the physicochemical quality of the harvested crop. However, despite increasing production and consumption of these vegetables in Brazil, most of the technical information available is related to yield variables. Research on physicochemical characteristics is scarce (Torres et al., 2017).

As such, this study aimed to assess the agronomic characteristics and physicochemical quality of green and sweet corn grains grown under succession planting using different cover crops.

\section{MATERIAL AND METHODS}

The study was conducted in an experimental area belonging to the vegetable crop sector of the Federal Institute of Education, Science and Technology of the Mineiro Triangle on the Uberaba Campus in Minas Gerais state, Brazil (19 $45^{\prime} 27^{\prime \prime} \mathrm{S}$, $47^{\circ} 55^{\prime} 36^{\prime \prime} \mathrm{W}, 764 \mathrm{~m}$ altitude). The area was in its first year of no-till planting and had previously been used for leafy vegetables.

Climate in the region is Aw, classified as warm tropical according to Beck et al. (2018), with hot rainy summers and cold dry winters. Average annual rainfall and temperature are $1600 \mathrm{~mm}$ and $22.6^{\circ} \mathrm{C}$, respectively (Inmet, 2019). The cover crops were grown in November and December 2018 and January 2019, with monthly rainfall of 370,314 and $70 \mathrm{~mm}$, respectively, totaling $754 \mathrm{~mm}$ for the period. Green and sweet corn were sown in February 2019 and harvested in May 2019. Rainfall in February, March, April and May 2019 was 91, 585, 69 and 51 $\mathrm{mm}$, respectively, totaling $796 \mathrm{~mm}$ for the four-month period.

Soil in the area was classified as medium-textured dystrophic red latosol (Santos et al., 2018), and exhibited the following attributes in the $0-0.20 \mathrm{~m}$ layer two months after liming: 210 , 710 and $80 \mathrm{~g} \mathrm{~kg}^{-1}$ clay, sand and silt, respectively, $5.6 \mathrm{pH}\left(\mathrm{CaCl}_{2}\right) ; 34.9 \mathrm{mg}$ $\mathrm{dm}^{-3} \mathrm{P}$ (resin); $2.88 \mathrm{mmol}_{\mathrm{c}} \mathrm{dm}^{-3} \mathrm{~K}^{+} ; 22.5$ mmol $\mathrm{dm}^{-3} \mathrm{Ca}^{2+} ; 7.00 \mathrm{mmol}_{\mathrm{c}} \mathrm{dm}^{-3} \mathrm{Mg}^{2+}$; $19 \mathrm{mmol}_{\mathrm{c}} \mathrm{dm}^{-3}$ potential acidity $(\mathrm{H}+\mathrm{Al})$, $63 \%$ base saturation, $23.8 \mathrm{~g} \mathrm{dm}^{-3}$ organic matter content and $53 \mathrm{mmol}_{\mathrm{c}} \mathrm{dm}^{-3} \mathrm{CEC}$.

Two experiments were conducted, one with green corn and the other sweet corn, both using a randomized block design with four repetitions and seven treatments, consisting of the cover crops grown alone or intercropped.

The treatments consisted of the cover crops brachiaria (Urochloa brizantha $\mathrm{cv}$. 'Marandu') (B); Pearl millet ADR 500 (Pennisetum glaucum) (PM); showy crotalaria (Crotalaria spectabillis) $(\mathrm{C})$; showy crotalaria + brachiaria $(\mathrm{SC}+\mathrm{B})$; Pearl millet + brachiaria $(\mathrm{PM}+\mathrm{B})$; Pearl millet + showy crotalaria $(\mathrm{PM}+\mathrm{SC})$ and Pearl millet + showy crotalaria + brachiaria $(\mathrm{PM}+\mathrm{SC}+\mathrm{B})$. The area of each plot was $12 \mathrm{~m}^{2}(4 \times 3 \mathrm{~m})$.

Conventional tillage was used to prepare the soil for the cover crops. Next, a mechanical seed drill was used, programmed for $0.20 \mathrm{~m}$ between rows, totaling 30 four-meter-long rows, with $15(\mathrm{C}), 50(\mathrm{~B})$ and $60(\mathrm{M})$ seeds per row for cover crops grown individually. For the intercropped treatments $\mathrm{SC}+\mathrm{B}$, $\mathrm{SC}+\mathrm{PM}, \mathrm{B}+\mathrm{PM}$ and $\mathrm{PM}+\mathrm{B}+\mathrm{SC}$, the number of seeds per row of each cover crop species was halved.

When approximately $50 \%$ of the plants reached peak flowering, about 90 days after sowing (DAS), samples were collected from an area of $2 \mathrm{~m}^{2}$ per plot, within the 22 center rows, removing all the plant material present on the soil.

After cover crop sampling to determine fresh (FW) and dry weight (DW), crop management was performed, which consisted of desiccating the total area using $2 \mathrm{~kg} \mathrm{ha}^{-1}$ of a commercial herbicide (Roundup $\mathrm{WG}^{\mathrm{R}}$ ) whose active ingredient is $792.5 \mathrm{~g} \mathrm{~kg}^{-1}$ of $\mathrm{N}$-(phosphonomethyl) glycine.

The plant material was weighed immediately after sampling to determine FW. Next, DW was calculated by drying the material in an oven at $65^{\circ} \mathrm{C}$ for 72 hours and then weighed.

The crop residue decomposition rate was assessed using the litter bag method developed by Santos \& Whilford (1981) with $2-\mathrm{mm}$ mesh nylon litter bags measuring $0.04 \mathrm{~m}^{2}(0.20 \times 0.20 \mathrm{~m})$. For this purpose, $20 \mathrm{~g}$ cover crop shoots were placed in each bag, after drying the plant material in an oven at $65^{\circ} \mathrm{C}$ for 72 hours.

Four litter bags were placed in each plot seven days after green and sweet corn sowing, and one bag per plot was collected at each sampling, which occurred 15, 30, 60 and 90 days after litter bag placement.

After sample collection, the plant residue from each bag was manually cleaned over a sieve, dried in an oven at $65^{\circ} \mathrm{C}$ for 72 hours to determine dry weight $\left(\mathrm{t} \mathrm{ha}^{-1}\right)$.

The decomposition of plant residue was described using the exponential mathematical model $\mathrm{X}=\mathrm{Xoe^{-kt }}$ proposed by Thomas \& Asakawa (1993), where: $\mathrm{X}$ is the dry weight (DW) remaining after time ( $\mathrm{t}$ ), in days; $\mathrm{X}_{\mathrm{o}}$ the initial DW; and $\mathrm{k}$ the decomposition constant.

Based on the $\mathrm{k}$ value, the half-life $\left(\mathrm{T}^{1 / 2}\right)$ of the remaining residue was calculated using the formula $\mathrm{T}^{1 / 2}=$ $0.693 / \mathrm{k}$, proposed by Paul \& Clark (1996), which expresses the time taken for half the residue to decompose. Mathematical equations for dry biomass (DB) decomposition were created using SigmaPlot software, version 10.

The sweet and green corn hybrids used were Thunder Attribute and VT PRO2 ${ }^{\text {tm }}$, respectively, the former supplied by Syngenta and the latter by Biomatrix, both recommended for cultivation in the region with a population of 60,000 plants per hectare. The hybrids are genetically modified, with an early cycle of 90 to 105 days, and resistant to the main corn pests and 
the active ingredient glyphosate.

In each plot, sweet and green corn seeds were sown in 6 rows spaced $0.50 \mathrm{~m}$ apart, with the four center rows considered the study area, totaling 8.0 $\mathrm{m}^{2}$.

Base fertilization was performed at sowing, considering the chemical attributes of the soil, using 32,112 and $64 \mathrm{~kg} \mathrm{ha}^{-1}$ of $\mathrm{N}, \mathrm{P}_{2} \mathrm{O}_{5}$ and $\mathrm{K}_{2} \mathrm{O}$, respectively, with the 4-14-8 formulation as source. Topdressing consisted of 70 $\mathrm{kg} \mathrm{ha}^{-1}$ of $\mathrm{N}$ and $70 \mathrm{~kg} \mathrm{ha}^{-1}$ of $\mathrm{K}_{2} \mathrm{O}$ (20-00-20 formulation) applied at 20 DAS, and $70 \mathrm{~kg} \mathrm{ha}^{-1}$ of $\mathrm{N}$ at 40 DAS, using urea with $45 \% \mathrm{~N}$ as source. The amount of fertilizer used was based on the doses reported by Freire et al. (1999) and Charlo et al. (2020) for green corn. Base fertilization was mechanized and topdressing was performed manually.

Pest and disease control measures were implemented when damagecausing levels of pests or pathogens were observed, by spraying insecticides and/or pesticides. Herbicides were also applied to control weed populations. All the agrochemicals used were registered for the crop in question and applied at the doses recommended by manufacturers.

Corn plants were manually harvested from the study area of the plots when the average grain moisture content was $73 \%$, in accordance with Parentoni et al. (1990) who recommended harvesting at a moisture content between 72 and $75 \%$. Twenty-four ears of corn were collected from the study area of green and sweet corn plots and then weighed to calculate yield in t ha ${ }^{-1}$. Next, 12 of the 24 ears of corn were randomly selected and submitted to husking and shelling (sweet and green corn) using knives, in order to determine the yield of sweet corn grains and green corn ears.

Yield was calculated after the sweet corn ears had been processed (husking and shelling), with values expressed in $\mathrm{t} \mathrm{ha}^{-1}$ and percentage (\%).

After shelling, green and sweet corn grains were analyzed to determine moisture content (MC), ash content (AC), lipids (LIP), proteins (PTN), carbohydrates (CARB), total soluble solids (TSS), titratable acidity (TA),
$\mathrm{pH}$ and ascorbic acid content (AA). The following methods were used: MC by gravimetric analysis; PTN with the Kjeldahl method, by determining nitrogen content using a correction factor of 6.25; LIP by Soxhlet extraction (gravimetry), based on the amount of material solubilized by the solvent; and AA using Tillman's method, as described by the Association of Official Analytical Chemists (AOAC, 2005). Ash content (AC) was measured by calcining the sample in a muffle furnace at $550^{\circ} \mathrm{C}$, until light gray ash was obtained.

TA was determined according to the methodology of the Instituto Adolfo Lutz (IAL, 1985), $\mathrm{pH}$ by a $\mathrm{pH}$ meter for a sample at $25^{\circ} \mathrm{C}$, measured with a thermometer; TSS using an electronic refractometer, CARB by difference $[100-(\%$ moisture $+\%$ ash $+\%$ lipids $+\%$ protein $+\%$ fiber)] and total energy content by adding the energy content of each food component (IAL, 2008). PTN and LIP were determined using dried samples and the remaining analyses were performed with fresh plant material, 24 hours after harvesting. During this period, the material was kept refrigerated in plastic bags, in stacks of five bags each.

The data were tested for normality and homogeneity of variance, using the Shapiro-Wilk and Bartlett tests, respectively. After, data were submitted to analysis of variance using the F-test, and means were compared using the Scott-Knott test at 5\% probability.

Table 1. Dry (DW, $\left.\mathrm{t} \mathrm{ha}^{-1}\right)$ and fresh weight $\left(\mathrm{FW}, \mathrm{t} \mathrm{ha}^{-1}\right)$ production of the different cover crops. Uberaba, IFTM, 2019.

\begin{tabular}{lcl}
\hline Cover crop & FW & DW \\
\hline Brachiaria (B) & $17.21 \mathrm{~b}$ & $4.82 \mathrm{~b}$ \\
Pearl millet (PM) & $31.37 \mathrm{a}$ & $8.44 \mathrm{a}$ \\
Showy crotalaria (SC) & $35.18 \mathrm{a}$ & $9.85 \mathrm{a}$ \\
B+PM & $26.22 \mathrm{a}$ & $7.34 \mathrm{a}$ \\
$\mathrm{B}+\mathrm{SC}$ & $27.79 \mathrm{a}$ & $7.78 \mathrm{a}$ \\
$\mathrm{PM}+\mathrm{SC}$ & $29.08 \mathrm{a}$ & $8.14 \mathrm{a}$ \\
$\mathrm{B}+\mathrm{SC}+\mathrm{PM}$ & $28.72 \mathrm{a}$ & $8.04 \mathrm{a}$ \\
$\mathrm{F}$ & $8.89^{* *}$ & $7.51^{* *}$ \\
\hline $\mathrm{CV}(\%)$ & 13.30 & 14.28 \\
\hline
\end{tabular}

**Significant $(\mathrm{p}<0,05)$. Means followed by the same letter in the column do not differ according to the Scott-Knott test $(\mathrm{p}=0.05)$.

\section{RESULTS AND DISCUSSION}

Analysis of FW and DW demonstrated that all the cover crops studied exhibited similar production, except brachiaria, which obtained lower values (Table 1). These results can be explained by the good rainfall distribution during the study period and soil fertility in the area, providing suitable soil and climate conditions for plant development and producing high FW and DW values.

The species studied here (brachiaria, Pearl millet and showy crotalaria) are noteworthy for the quantity and quality of $\mathrm{FW}$ and DW produced in the Brazilian Cerrado and are therefore widely used as cover crops under no-till systems in the region (Assis et al., 2013; Pacheco et al., 2013).

Under natural conditions during the rainy season, Pearl millet, brachiaria and showy crotalaria produced dry weight of 6.0 to $13.0 \mathrm{t} \mathrm{ha}^{-1}, 7.0$ to $12.0 \mathrm{t} \mathrm{ha}^{-1}$ and 4.0 to $9.0 \mathrm{t} \mathrm{ha}^{-1}$, respectively. These plants provide high nutrient cycling when compared to others used in the region (Assis et al., 2013, Pacheco et al., 2013; Torres et al., 2014; Collier et al., 2018; Mazetto Junior et al., 2019).

Analysis of the residue decomposition rate showed 51.8; 68.9 and $71.1 \% \mathrm{~B}, \mathrm{PM}$ and $\mathrm{SC}$ remained after 90 days in the individually-grown treatments, and $63.1 ; 67.8 ; 72.2$ and $69.8 \%$ for the intercropped treatments $\mathrm{B}+\mathrm{SC}, \mathrm{B}+\mathrm{PM}, \mathrm{PM}+\mathrm{SC}$ and $\mathrm{B}+\mathrm{SC}+\mathrm{PM}$, 
respectively (Figure 1). This indicates faster decomposition when brachiaria was present, either alone or intercropped

Crotalaria (Fabaceae) generally produces less FW and DW when compared to Pearl millet and brachiaria (Poaceae), as shown in other studies that assess these plants (Soratto et al., 2012; Torres et al., 2014). However, this did not occur in the present study, since fresh and dry weight production in showy crotalaria was similar to that of the other cover crops.

Although Fabaceae typically exhibit lower carbon-to-nitrogen ratios $(\mathrm{C}: \mathrm{N})$ than Poaceae due to high biological nitrogen fixation (Pacheco et al., with showy crotalaria.

2013), in this study treatments with showy crotalaria did not exhibit higher decomposition rates, either when grown alone or intercropped.

However, high decomposition rates were observed for treatments with only brachiaria or when combined with showy crotalaria, likely because slow initial growth meant the plant had not reached the flowering stage when the herbicide was applied.

The decomposition constant (k) of the regression curves was used to estimate the half-life $\left(\mathrm{T}^{1 / 2}\right)$ of the crop residues, indicating faster decomposition when brachiaria (B) was grown alone or intercropped with showy crotalaria, since half the residues

Table 2. Decomposition constant $\left(\mathrm{k}, \mathrm{g} \mathrm{g}^{-1}\right)$ and half-life $\left(\mathrm{T}^{1 / 2}\right.$, days) of the remaining dry weight of different cover crops grown in an area used for no-till cultivation of irrigated vegetables. Uberaba, IFTM, 2019.

\begin{tabular}{lcccc}
\hline \multirow{2}{*}{ Cover crop } & \multicolumn{4}{c}{ Remaining dry weight } \\
\cline { 2 - 5 } & Total & $\mathbf{k}$ & $\mathbf{T}^{1 / 2}$ & $\mathbf{R}^{2}$ \\
\hline Brachiaria (B) & $4.82 \mathrm{~b}$ & 0.0249 & $28 \mathrm{c}$ & $0.99^{*}$ \\
Pearl millet (PM) & $8.44 \mathrm{a}$ & 0.0087 & $80 \mathrm{a}$ & 0.99 \\
Showy crotalaria (SC) & $9.85 \mathrm{a}$ & 0.0107 & $65 \mathrm{a}$ & 0.99 \\
B+SC & $7.78 \mathrm{a}$ & 0.0165 & $42 \mathrm{~b}$ & 0.99 \\
B+PM & $7.34 \mathrm{a}$ & 0.0099 & $70 \mathrm{a}$ & 0.99 \\
PM+SC & $8.14 \mathrm{a}$ & 0.0095 & $73 \mathrm{a}$ & 0.99 \\
B+SC+PM & $8.04 \mathrm{a}$ & 0.0105 & $66 \mathrm{a}$ & 0.99 \\
\hline F & $7.51^{*}$ & -- & $4.54^{* *}$ & -- \\
CV (\%) & 14.28 & -- & 17.39 & -- \\
\hline
\end{tabular}

***Significant $(\mathrm{p}<0.01 ; \mathrm{p}<0.05) ; \mathrm{R}^{2}=$ Coefficient of determination. Means followed by the same letter in the column do not differ according to the Scott-Knott test $(\mathrm{p}=0.05)$.

Table 3. Agronomic characteristics of sweet corn grown on different cover crop residues, in the 2018/2019 growing season. Uberaba, IFTM, 2019.

\begin{tabular}{lccccc}
\hline \multirow{2}{*}{ Cover crop } & Husk & Ear & PEH & PGrain & \multirow{2}{*}{ GY (\%) } \\
\cline { 2 - 5 } & \multicolumn{5}{c}{$\left(\mathbf{t ~ h a}^{-1}\right)$} \\
Brachiaria (B) & 2.02 & 2.51 & 6.52 & 1.99 & 30.52 \\
Pearl millet (PM) & 2.51 & 2.29 & 7.52 & 2.72 & 36.17 \\
Showy crotalaria (SC) & 2.70 & 2.38 & 8.13 & 3.05 & 37.51 \\
B+PM & 2.40 & 2.43 & 7.94 & 3.11 & 39.17 \\
B+SC & 2.41 & 2.20 & 7.63 & 3.02 & 39.58 \\
SC+PM & 2.50 & 3.17 & 8.46 & 2.79 & 31.98 \\
PM+SC+B & 2.55 & 2.31 & 7.92 & 3.06 & 38.64 \\
\hline F & $1.46^{\text {ns }}$ & $0.97^{\text {ns }}$ & $1.61^{\text {ns }}$ & $1.03^{\text {ns }}$ & $1.34^{\text {ns }}$ \\
CV (\%) & 14.33 & 17.04 & 20.76 & 21.06 & 24.21 \\
\hline
\end{tabular}

${ }^{\mathrm{s}}$ Not significant. Means followed by the same letter in the column do not differ according to the Scott-Knott test $(\mathrm{p}=0.05) . \mathrm{PEH}=$ Productivity of the ear with husk; PGrain $=$ Corn grain productivity; $\mathrm{GY}=$ Grain yield. of these crops had decomposed at 28 and 42 days, respectively. However, in the remaining treatments, between 70 and 128 days (Table 2), these rates may vary according to the plant species used.

It should be noted that the $\mathrm{C}: \mathrm{N}$ ratio, temperature and soil moisture content are important factors that influence the speed of residue decomposition. Fabaceae plants decompose faster under a monoculture system, while Fabaceae + Poaceae combinations exhibit intermediate decomposition when compared to Poaceae plants grown alone. Crops with a low C:N ratio, such as Fabaceae, have higher decomposition rates and their residue remains in the soil for less time than those with a high $\mathrm{C}: \mathrm{N}$ ratio, as demonstrated in previous studies (Soratto et al., 2012; Torres et al., 2019).

According to Giacomini et al. (2003), intercropping plants from different families with inversely proportional $\mathrm{C}: \mathrm{N}$ ratios, such as Fabaceae and Poaceae, produces plants with intermediate $\mathrm{C}: \mathrm{N}$, resulting in a lower decomposition rate and providing soil cover for longer time, as observed in the present study.

Torres et al. (2008) and Pacheco et al. (2013) found that decomposition is directly influenced by temperature and soil moisture content, since it increases concomitantly to the rise in these variables during the rainy season, and declines to minimal values in the dry season.

In the present study, at the stage in which herbicide was applied, brachiaria plants exhibited a low $\mathrm{C}: \mathrm{N}$ ratio because they had not yet reached maximum flowering. As such, it can be inferred that this accelerated residue decomposition because temperature and moisture content were suitable and varied little during this period. This is evident in the shorter half-life observed ( 28 days), which also declined in treatments $\mathrm{B}+\mathrm{SC}$ (42 days), $\mathrm{B}+\mathrm{PM}$ (70 days) and $\mathrm{B}+\mathrm{SC}+\mathrm{PM}$ (66 days).

Assis et al. (2013) and Mazetto Júnior et al. (2019) found similar results when brachiaria was used as cover crop due to its faster decomposition when compared to Pearl millet and sunn hemp (crotalaria), proving that the low $\mathrm{C}: \mathrm{N}$ 
ratio of the crop accelerated residue decomposition.

In a similar study conducted in the same region, Torres et al. (2008) assessed the biomass production and residue mineralization of different cover crops in areas used for corn and soybean cultivation under no-till system and found a longer $\mathrm{T}^{1 / 2}$ for Pearl millet (131 days) and sunn hemp (98 days), when compared to brachiaria (56 days).

In the 2008/09 and 2009/10 growing

Table 4. Agronomic characteristics of green corn grown on different cover crop residues, in the 2018/19 growing season. Uberaba, IFTM, 2019.

\begin{tabular}{|c|c|c|c|c|}
\hline \multirow{2}{*}{ Cover crop } & PEH & Husk & PEWH & \multirow{2}{*}{ EY (\%) } \\
\hline & & $\left(\mathrm{t} \mathrm{ha}^{-1}\right)$ & & \\
\hline Brachiaria (B) & 10.64 & $3.62 b$ & 7.01 & 65.84 \\
\hline Pearl millet (PM) & 10.87 & $4.53 \mathrm{a}$ & 7.18 & 66.13 \\
\hline Showy crotalaria (SC) & 10.06 & $3.39 b$ & 6.70 & 66.66 \\
\hline $\mathrm{B}+\mathrm{PM}$ & 10.18 & $4.04 \mathrm{a}$ & 6.87 & 67.54 \\
\hline $\mathrm{B}+\mathrm{SC}$ & 10.91 & $3.96 \mathrm{a}$ & 7.20 & 66.08 \\
\hline $\mathrm{SC}+\mathrm{PM}$ & 10.91 & $3.26 \mathrm{~b}$ & 6.73 & 62.53 \\
\hline $\mathrm{PM}+\mathrm{SC}+\mathrm{B}$ & 10.47 & $3.50 \mathrm{~b}$ & 6.85 & 62.53 \\
\hline $\mathrm{F}$ & $0.81^{\mathrm{ns}}$ & $3.01^{* *}$ & $0.47^{\mathrm{ns}}$ & $0.42^{\mathrm{ns}}$ \\
\hline CV (\%) & 7.44 & 13.60 & 8.50 & 7.38 \\
\hline
\end{tabular}

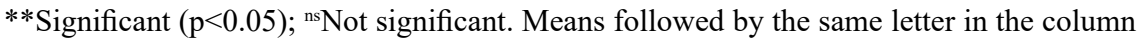
do not differ according to the Scott-Knott test $(\mathrm{p}=0.05)$. PEH = Productivity of the ear with husk, $\mathrm{PEWH}=$ Productivity of the ear without husk, EY = Ear yield.

seasons, Pacheco et al. (2013) recorded $\mathrm{T}^{1 / 2}$ of 42 and 111 days for brachiaria, 63 and 108 days for pear millet and 44 and 130 days for brachiaria + pigeon pea combined, respectively. Collier et al. (2018) reported $\mathrm{T}^{1 / 2}$ of 57 days for sunn hemp submitted to a second harvest 170 days after sowing.

In a similar study using the same cover crops, but conducted in Uberlândia (MG) in more fertile clayey red latosol, Miranda et al. (2020) observed higher $\mathrm{FW}$ and DW production in the $\mathrm{PM}+\mathrm{B}$ treatment, but lower FW for sunn hemp $(\mathrm{SH})$ alone and $\mathrm{PM}+\mathrm{SH}$. The same authors reported that the highest DW production was recorded for the sunn hemp and $\mathrm{SH}+\mathrm{B}$ treatments, unlike the results obtained in the present study.

Analysis of the production parameters for sweet corn grown on different cover crop residues indicated no significant statistical difference between treatments for any of the variables quantified (Table 3). Nevertheless, ear productivity and grain yield were high,

Table 5. Bromatological characteristics of green and sweet corn grown using different cover crops. Uberaba, IFTM, 2019.

\begin{tabular}{|c|c|c|c|c|c|c|c|c|c|}
\hline \multirow{2}{*}{ Cover crop } & MC & ASH & LIP & PTN & CARB & \multirow{2}{*}{$\begin{array}{c}\text { TA } \\
\left(\text { meq L L }^{-1}\right)\end{array}$} & \multirow{2}{*}{$\begin{array}{c}\text { TSS } \\
\text { ( }{ }^{\circ} \text { Brix) }\end{array}$} & pH & $\mathbf{A A}$ \\
\hline & & & $(\%)$ & & & & & \multicolumn{2}{|c|}{$\left(\mathrm{mg} \mathrm{100g^{-1 } )}\right.$} \\
\hline & \multicolumn{9}{|c|}{ Green corn } \\
\hline Brachiaria (B) & $67.8 \mathrm{a}$ & 2.5 & 2.7 & 12.6 & 76.8 & $1.9 \mathrm{c}$ & $12.4 \mathrm{a}$ & 6.9 & 11.2 \\
\hline Pearl millet (PM) & $60.9 b$ & 2.3 & 3.4 & 11.6 & 75.8 & $1.8 \mathrm{c}$ & $9.9 b$ & 7.1 & 10.0 \\
\hline Showy crotalaria (SC) & $56.2 b$ & 2.3 & 2.7 & 10.8 & 77.9 & $2.8 \mathrm{~b}$ & $9.9 \mathrm{~b}$ & 7.0 & 10.2 \\
\hline $\mathrm{B}+\mathrm{PM}$ & $75.4 \mathrm{a}$ & 2.4 & 2.9 & 12.4 & 77.8 & $3.5 \mathrm{a}$ & $12.2 \mathrm{a}$ & 6.6 & 11.7 \\
\hline $\mathrm{B}+\mathrm{SC}$ & $59.8 \mathrm{~b}$ & 2.3 & 2.8 & 13.3 & 75.4 & $2.7 \mathrm{~b}$ & $13.2 \mathrm{a}$ & 7.1 & 10.3 \\
\hline $\mathrm{PM}+\mathrm{SC}$ & $57.1 \mathrm{~b}$ & 2.5 & 3.0 & 12.3 & 76.7 & $2.5 \mathrm{~b}$ & $9.3 b$ & 6.8 & 10.7 \\
\hline $\mathrm{B}+\mathrm{SC}+\mathrm{PM}$ & $77.7 \mathrm{a}$ & 2.6 & 2.5 & 12.4 & 74.8 & $2.0 \mathrm{c}$ & $10.6 \mathrm{~b}$ & 6.9 & 11.0 \\
\hline $\mathrm{F}$ & $3.34 *$ & $0.59^{\mathrm{ns}}$ & $1.12^{\mathrm{ns}}$ & $1.74^{\mathrm{ns}}$ & $0.86^{\mathrm{ns}}$ & $6.06^{* *}$ & $14.49 * *$ & $0.64^{\mathrm{ns}}$ & $1.57^{\mathrm{ns}}$ \\
\hline \multirow[t]{2}{*}{ CV (\%) } & 12.58 & 13.68 & 14.37 & 7.50 & 3.25 & 19.71 & 6.73 & 7.34 & 7.95 \\
\hline & \multicolumn{9}{|c|}{ Sweet corn } \\
\hline Brachiaria (B) & 78.5 & 2.3 & $3,9 b$ & $12.7 \mathrm{~b}$ & 71.1 & 2.9 & $11.8 \mathrm{~b}$ & $5.6 \mathrm{~b}$ & $14.0 \mathrm{a}$ \\
\hline Pearl millet (PM) & 77.9 & 2.3 & $4,8 \mathrm{a}$ & $13.8 \mathrm{~b}$ & 69.6 & 2.8 & $14.4^{\mathrm{a}}$ & $6.5 \mathrm{a}$ & $12.1 \mathrm{~b}$ \\
\hline Showy crotalaria SC) & 79.6 & 2.3 & $3,9 b$ & $13.0 \mathrm{~b}$ & 72.4 & 2.5 & $11.2 \mathrm{~b}$ & $6.5 \mathrm{a}$ & $10.6 \mathrm{~b}$ \\
\hline $\mathrm{B}+\mathrm{PM}$ & 77.8 & 2.3 & $4,9 \mathrm{a}$ & $14.9 \mathrm{a}$ & 68.3 & 2.7 & $13.4^{\mathrm{a}}$ & $6.9 \mathrm{a}$ & $12.0 \mathrm{~b}$ \\
\hline $\mathrm{B}+\mathrm{SC}$ & 81.1 & 2.6 & $3,9 b$ & $12.9 \mathrm{~b}$ & 70.8 & 3.4 & $12.2 \mathrm{~b}$ & $6.1 \mathrm{~b}$ & $12.8 \mathrm{a}$ \\
\hline $\mathrm{PM}+\mathrm{SC}$ & 68.6 & 2.3 & $3,2 b$ & $13.2 b$ & 72.4 & 2.4 & $13.7^{\mathrm{a}}$ & $6.6 \mathrm{a}$ & $11.9 \mathrm{~b}$ \\
\hline $\mathrm{B}+\mathrm{SC}+\mathrm{PM}$ & 68.4 & 2.38 & $4,7 \mathrm{a}$ & $15.5 \mathrm{a}$ & 71.1 & 2.4 & $12.9^{\mathrm{a}}$ & $6.5 \mathrm{a}$ & $12.5 \mathrm{a}$ \\
\hline $\mathrm{F}$ & $1.58^{\mathrm{ns}}$ & $0.44^{\mathrm{ns}}$ & $4.92 * *$ & $3.17 * *$ & $1.27^{\mathrm{ns}}$ & $2.22^{\mathrm{ns}}$ & $8.15^{* *}$ & $3.13^{*}$ & $4.80 * *$ \\
\hline CV $(\%)$ & 12.58 & 11.01 & 17.46 & 10.75 & 3.73 & 19.18 & 6.58 & 6.75 & 8.73 \\
\hline
\end{tabular}

**Significant $(\mathrm{p}<0,05)$. Means followed by the same letter in the column do not differ according to the Scott-Knott test ( $\mathrm{p}=0.05)$. Moisture content (MC), ash (ASH), lipids (LIP), proteins (PTN), carbohydrates (CARB), total soluble solids (TSS), titratable acidity (TA), potential of hydrogen $(\mathrm{pH})$ and ascorbic acid (AA). 
varying from 6.52 to $8.46 \mathrm{tha}^{-1}$ and 1.99 to $3.1 \mathrm{t} \mathrm{ha}^{-1}$, respectively.

Pedrotti et al. (2015) studied the yield of sweet corn grown on sunn hemp, pigeon pea, bean and peanut residues and found values of $9.4 ; 7.7 ; 6.8$ and $6.6 \mathrm{t} \mathrm{ha}^{-1}$, with significantly higher yields for sunn hemp when compared to the other cover crops, despite the fact they were all Fabaceae species, with excellent nitrogen fixing capacity. Additionally, the authors emphasized that the productivity of commercial ears of corn reached $95 \%$ under a no-till system, and 88 and $85 \%$ for minimum and conventional tillage, respectively.

In the present study, there were no significant differences for most of the yield variables assessed, except for husk production, which was higher in the Pearl millet, $\mathrm{B}+\mathrm{SC}$ and $\mathrm{B}+\mathrm{PM}$ treatments (Table 4). The absence of statistically significant effects in the variables measured for both green and sweet corn can be explained by the good initial soil fertility, especially in terms of $\mathrm{P}$ and $\mathrm{K}$ content $\left[34.9 \mathrm{mg} \mathrm{dm}^{-3}\right.$ of $\mathrm{P}$ (resin) and $2.88 \mathrm{mmol}_{\mathrm{c}} \mathrm{dm}^{-3}$ of $\mathrm{K}^{+}$, as well as $\mathrm{Ca}$ and $\mathrm{Mg}$. Moreover, base fertilization and topdressing (total of
$132 \mathrm{~kg} \mathrm{ha}^{-1}$ of $\mathrm{N} ; 110 \mathrm{~kg} \mathrm{ha}^{-1}$ of $\mathrm{P}_{2} \mathrm{O}_{5}$ and $134 \mathrm{~kg} \mathrm{ha}^{-1}$ of $\mathrm{K}_{2} \mathrm{O}$ ) likely met the needs of the green and sweet corn crops, regardless of the nutrients released by the cover crops used.

In the production of sweet corn derivatives, such as pamonha (corn cakes), cultivars must exhibit good husk quality, which helps maintain grain moisture content and conserves the ears (Pereira Filho \& Cruz, 2002).

Pinho et al. (2008) studied the quality of green corn under organic and conventional production systems and found that the average husk weight per ear varied from 118.7 to 146.0 grams under these systems, lower than the value obtained here for green corn (156.2 grams) grown on Pearl millet residue.

The yield variables assessed for green and sweet corn indicate that plants collected at a moisture content of $70 \%$ up to 90 days after sowing are not affected by the type of cover crop used. This differs from the findings of other studies, since Torres et al. (2014) observed increased production when corn was grown on Fabaceae species, particularly sunn hemp.

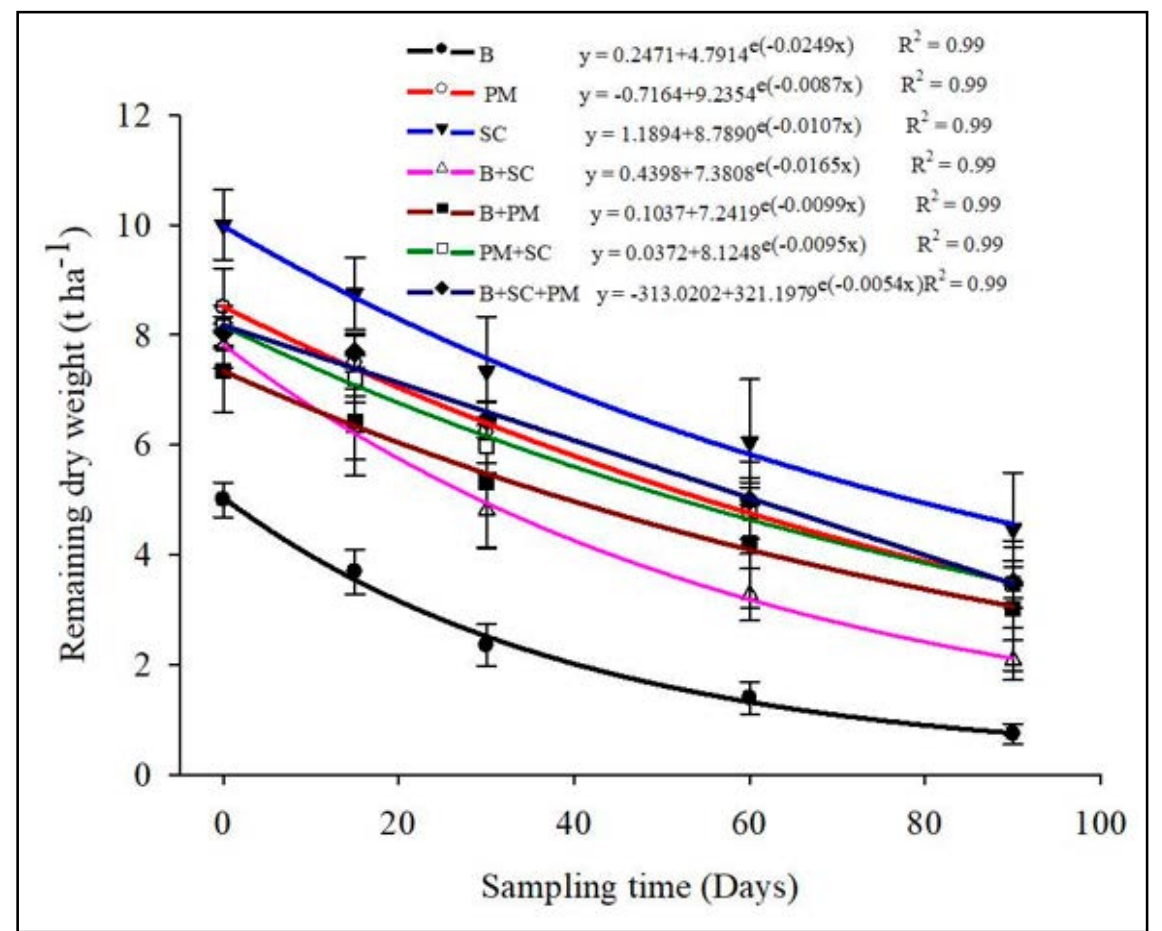

Figure 1. Remaining dry weight of residue from the brachiaria (B), Pearl millet (M), showy crotalaria (SC) and $\mathrm{B}+\mathrm{SC}, \mathrm{B}+\mathrm{PM}, \mathrm{PM}+\mathrm{SC}$ and $\mathrm{B}+\mathrm{SC}+\mathrm{PM}$ treatments, $0,15,30,60$ and 90 days after litter bag distribution. Uberaba, IFTM, 2019.
According to Luz et al. (2014), green corn must be harvested at the ideal moisture content of 70 to $78 \%, 28$ to 30 days after flowering, because moisture content directly influences post-harvest quality, adding value to the product.

The moisture content (MC) of green corn was higher when grown on brachiaria residue and in the $\mathrm{B}+\mathrm{PM}$ and $\mathrm{B}+\mathrm{PM}+\mathrm{SC}$ treatments $(68,75$ and $78 \%$, respectively). However, in another study with green corn, Pinho et al. (2008) found MC values between $80 \% \pm 4.6$ and $81 \% \pm 3.2$, respectively, higher than those obtained here, which were close to optimal.

The cover crops influenced the bromatological characteristics of green corn. Moisture content (MC), titratable acidity (TA) and total soluble solids (TSS) were statistically superior in green corn grown on (B) brachiaria residue alone or intercropped with other soil cover plants [brachiaria + showy crotalaria $(\mathrm{B}+\mathrm{SC})$, brachiaria + Pearl millet $(\mathrm{B}+\mathrm{PM})$ and brachiaria + showy crotalaria + Pearl millet $(\mathrm{B}+\mathrm{SC}+\mathrm{PM})]$ (Table 5).

However, these bromatological characteristics were not affected in sweet corn, since significant alterations were recorded in other parameters assessed. The highest lipid concentrations were obtained in sweet grains cultivated using Pearl millet (PM) residue alone or intercropped with other cover plants, while the largest protein contents were recorded in treatments $\mathrm{B}+\mathrm{PM}$ and $\mathrm{B}+\mathrm{SC}+\mathrm{PM}$.

Statistically superior $\mathrm{pH}$ values were observed in sweet corn under the showy crotalaria, Pearl millet, $\mathrm{B}+\mathrm{PM}$, $\mathrm{PM}+\mathrm{SC}$ and $\mathrm{B}+\mathrm{SC}+\mathrm{PM}$ treatments, whereas brachiaria in monoculture and the $\mathrm{B}+\mathrm{SC}$ and $\mathrm{B}+\mathrm{SC}+\mathrm{PM}$ treatments resulted in the highest ascorbic acid (AA) concentrations. By contrast, Pearl millet alone and in $\mathrm{B}+\mathrm{PM}, \mathrm{PM}+\mathrm{SC}$ and $\mathrm{B}+\mathrm{SC}+\mathrm{PM}$ produced the highest total soluble solids (TSS) values.

In the present study, TA varied from 1.8 to $3.5 \mathrm{meq} \mathrm{L}^{-1}$ and 2.4 to $3.4 \mathrm{meq} \mathrm{L}^{-1}$ for green and sweet corn, respectively, higher than those found by Pinho et al. (2008) in specialty corn varieties. The authors found average malic acid content from 1.20 to $1.8 \%$, indicating 
that $\mathrm{B}+\mathrm{PM}$ residue increased $\mathrm{TA}$ in green and sweet corn, ensuring better conservation of the product. Pinho et al. (2003) assessed the physical and chemical characteristics of corn cultivars for the production of baby corn and obtained TA of $3.5 \%$ malic acid.

The TSS values of green corn were greater when it was grown on $\mathrm{B}$ residue $\left(12.40^{\circ} \mathrm{Brix}\right)$ in monoculture or in the intercropped treatments $\mathrm{B}+\mathrm{SC}$ $\left(13.23^{\circ}\right.$ Brix) and $\mathrm{B}+\mathrm{PM}\left(12.2^{\circ} \mathrm{Brix}\right)$. This was also observed in sweet corn for plots with $\mathrm{PM}$ residue (14.4 $\left.{ }^{\circ} \mathrm{Brix}\right)$ in monoculture or $\mathrm{B}+\mathrm{PM}\left(13.4^{\circ} \mathrm{Brix}\right)$, $\mathrm{PM}+\mathrm{SC}\left(13.7^{\circ} \mathrm{Brix}\right)$ and $\mathrm{B}+\mathrm{SC}+\mathrm{PM}$ $\left(12.9^{\circ}\right.$ Brix) (Table 1). These findings indicate the positive influence of the cover crops used, since TSS increased in green and sweet corn grains grown on residues of Poaceae plants cultivated alone or intercropped.

Leme (2007) assessed and stored green corn hybrids aimed at pamonha production and found similar TSS results, with values ranging from 11.3 to $13.4^{\circ}$ Brix, whereas Pinho et al. (2008) recorded a lower value $\left(8.5^{\circ} \mathrm{Brix}\right)$ in green corn grown under organic and conventional systems.

In sweet corn, lipid (LIP) values were statistically equal in the PM residue treatment $(4.8 \%)$ as well as $\mathrm{B}+\mathrm{PM}$ $(4.9 \%)$ and $\mathrm{B}+\mathrm{SC}+\mathrm{PM}(4.7 \%)$, and statistically superior when compared to the other treatments $(\mathrm{B} ; \mathrm{SC} ; \mathrm{B}+\mathrm{SC}$ and $\mathrm{PM}+\mathrm{SC}$ ), corroborating the findings of other studies. Paes (2006) reported an ideal lipid content of approximately $4 \%$ for corn.

Protein (PTN) content was higher in $\mathrm{B}+\mathrm{PM}(14.9 \%)$ and $\mathrm{B}+\mathrm{PM}+\mathrm{C}(15.5 \%)$ when compared to the other treatments.

According to Franco (2005), the chemical composition and energy content for every $100 \mathrm{~g}$ fresh sweet corn are 386.5 calories, $66.7 \mathrm{~g}$ of glycine, $11.62 \mathrm{~g}$ of PTN, and $8.1 \mathrm{~g}$ of LIP, lower than the PTN and LIP values recorded in the present study. Torres et al. (2017) studied the chemical quality of brassica crops grown in the Cerrado on different cover crop residues and found higher PTN values for cauliflower cultivated with sunn hemp residue.

Statistically superior TSS and $\mathrm{pH}$ were obtained for sweet corn grains cultivated on Pearl millet residue in monoculture and $\mathrm{B}+\mathrm{PM}, \mathrm{PM}+\mathrm{SC}$ and $\mathrm{B}+\mathrm{PM}+\mathrm{SC}$. Respective TSS ( ${ }^{\circ}$ Brix) and $\mathrm{pH}$ values in these treatments were 14.4 and $6.5 ; 13.4$ and $6.9 ; 13.7$ and 6.6, and 12.9 and 6.5 (Table 5). Thus, the best results were obtained in the treatments that contained Pearl millet, either in monoculture or intercropped with other cover plants.

In similar studies that analyzed the physical and chemical parameters in sweet corn cultivars, Pinho et al. (2008) found TSS values between 15 and $17^{\circ}$ Brix, higher than those recorded here, indicating a low grain sugar content.

With respect to $\mathrm{pH}$, the results of the present study are similar to those of Leme (2007) and Pinho et al. (2008), who reported $\mathrm{pH}$ values of 6.7 and 6.8 when they assess the storage of green corn hybrids aimed at pamonha production grown under organic and conventional systems. Pinho et al. (2003) observed $\mathrm{pH}$ between 6.4 and 6.9 .

Once harvested, both green and sweet corn are highly perishable due to their elevated moisture content and less acid $\mathrm{pH}$, which favor the proliferation of microorganisms, thereby limiting the time available to commercialize these foods (Leme, 2007). In this context, brachiaria residue reduced the $\mathrm{pH}$ of sweet corn to 5.6, an important factor in its commercialization since high $\mathrm{pH}$ reduces the perishability and increases the shelf life of the product.

Ascorbic acid (AA) content was higher for the brachiaria treatment (14.0 $\left.\mathrm{mg} 100 \mathrm{~g}^{-1}\right)$, as well as B+SC (12.8 mg $\left.100 \mathrm{~g}^{-1}\right)$ and $\mathrm{B}+\mathrm{SC}+\mathrm{PM}$ (12.5 mg 100 $\mathrm{g}^{-1}$ ), indicating that sweet corn grown after a brachiaria crop in monoculture or intercropped with other cover plants, except for the B+PM treatment, positively influenced increased AA.

Pinho et al. (2003) studied the physical and chemical parameters of specialty corn cultivars and obtained AA content of 9.6 to $11.5 \mathrm{mg} 100 \mathrm{~g}^{-1}$. Torres et al. (2017) also reported a rise in AA levels when cauliflower and cabbage were grown on brachiaria residue.

According to the results obtained here, brachiaria was the cover crop that produced the lowest fresh and dry weight, highest residue decomposition rate and shortest half-life when compared to the other soil covers assessed.

Productivity and yield for sweet corn grains and green corn ears were not statistically affected by the different cover crop residues.

The different cover crop residues affected moisture content, titratable acidity, and total soluble solids in green corn, and lipids, proteins, total soluble solids, $\mathrm{pH}$ and ascorbic acid in sweet corn, indicating that the treatments interfered heterogeneously in the bromatological characteristics of green and sweet corn.

\section{ACKNOWLEDGMENTS}

The authors are grateful to the Federal Institute of Education, Science and Technology of the Mineiro Triangle for providing the necessary equipment and laboratory space to conduct the experiments and analyses, and to the Luiz de Queiroz Foundation for Agricultural Studies (Agrisus Foundation), Research Support Foundation of Minas Gerais State (FAPEMIG) and National Council for Scientific and Technological Development (CNPq) for the scholarships awarded to students and the funding provided.

\section{REFERENCES}

ASSIS, RL; OLIVEIRA, CAA; PERIN,A; SIMON GA; SOUZA JUNIOR, BA. 2013. Produção de biomassa, acúmulo de nitrogênio por plantas de cobertura e efeito na produtividade do milho safrinha. Enciclopédia Biosfera 9: 1769-1775.

ASSOCIATION OF OFFICIAL ANALYTICAL CHEMISTS (AOAC). 2005. Official Methods of analysis of AOAC International. 18. ed. Washington: AOAC.

BECK, HE; ZIMMERMANN, NE; Mc VICAR, TR; VERGOPOLAN, N; BERG, A; WOOD, EF. 2018. Present and future Köppen-Geiger climate classification maps at 1-km resolution. Sci Data 1: 1-12.

CHARLO, HCO; ALMEIDA, JSM; LANA, RMQ; CASTOLDI, R; MOREIRA, EFA; FRANCO JÚNIOR, MR; SANTOS, WB. 2020. Changes in chemical soil and corn yield after application of gypsum and potassium doses. Bioscience Journal 36: 810-826.

COLLIER, LS; ARRUDA, EM; CAMPOS, LFC; NUNES, JNV. 2018. Soil chemical attributes 
and corn productivity grown on legume stubble in agroforestry systems. Revista Caatinga 31 : 279-289.

COMPANHIA NACIONAL DE ABASTECIMENTO (CONAB). 2019. Acompanhamento da safra brasileira de grãos: safra 2017/18; 2018/19: Available http:// www.conab.gov.br/Conabweb/download/pdf. Accessed October 12, 2019.

FRANCO, G. 2005. Composição química dos alimentos e valor energético. In: Tabela de composição química dos alimentos. 9. ed. São Paulo: Atheneu, cap.2, p.107-152.

FREIRE, FM; FRANÇA, GE; VASCONCELLOS, CA; PEREIRA FILHO, IA; ALVES, VMC; PITTA, GVE. 1999. Milho Verde. In: RIBEIRO, AC; GUIMARÃES, PTG; ALVAREZ, VH. Recomendações para o uso de corretivos e fertilizantes em Minas Gerais - $5^{a}$ aproximação. Viçosa: UFV. p.195-196.

GIACOMINI, SJ; AITA, C; VENDRUSCOLO, ERO; CUBILLA, M; NICOLOSO, RS; FRIES, MR. 2003. Matéria seca, relação C/N e acúmulo de nitrogênio, fósforo e potássio em misturas de plantas de cobertura de solo. Revista Brasileira de Ciência do Solo 27: 325-334.

HORVATHY NETO, A; SILVA, AG; TEIXEIRA, IR; COSTA, KAP; ASSIS, RL. 2014. Consórcio de sorgo granífero e braquiária na safrinha para produção de grãos e forragem. Revista Caatinga 27: 132-141.

INSTITUTO ADOLFO LUTZ (IAL). 1985. Normas analíticas do Instituto Adolfo Lutz: métodos químicos e fisicos para análises de alimentos. $3^{\mathrm{a}}$. ed. SP. v.1, 533p.

INSTITUTO ADOLFO LUTZ (IAL). 2008. Yeast: Métodos físico-químicos para análises de alimentos. $4^{\circ} \mathrm{Ed}$. São Paulo: IAL, 1020p.

INSTITUTO NACIONALDE METEOROLOGIA (INMET). 2019. Informações sobre as condições climáticas do município de Uberaba-MG. Available http://www.inmet. gov.br. Accessed November 21, 2019.

LEME AC. 2007. Avaliação e armazenamento de hibridos de milho verde visando à produção de pamonha. Piracicaba: USP-ESALQ. 124p. (Ms.C. dissertation).

LUZ, JM; CAMILO, JS; BARBIERI, VH; RANGEL, RM; OLIVEIRA, RC. 2014. Produtividade de genótipos de milho doce e milho verde em função de intervalos de colheita. Horticultura Brasileira 32: 163-167.

MAZETO JÚNIOR, JC; TORRES, JLR; ALMEIDA, DDC; SILVA, VR; SOUZA,
ZM; LEMES, EM. 2019. Production and decomposition of cover crop residues and associations with soil organic fractions. Journal of Agricultural Science 11: 58-69.

MIRANDA, KFG; TORRES, JLR; CHARLO, HCO; ORIOLI JÚNIOR, V; FAVARO, JHS; SOUZA, ZM. 2020. Sweet corn in no-tillage system on cover crop residues in the Brazilian Cerrado. Australian Journal of Crop Science 14: 947-952.

OLIVEIRA, FCC; PEDROTTI, A; FELIX, AGS; SOUZA, JLS; HOLANDA, FSR; MELLO JUNIOR, AV. 2017. Características químicas de um Argissolo e a produção de milho verde nos Tabuleiros Costeiros sergipanos. Agrária 12: 354-360.

PACHECO, LP; BARBOSA, JM; LEANDRO, WM; MACHADO, PLOA; ASSIS, RL; MADARI, BE; PETTER, FA. 2013. Ciclagem de nutrientes por plantas de cobertura e produtividade de soja e arroz em plantio direto. Pesquisa Agropecuária Brasileira 48: 1228-1236.

PAES, MCD. 2006. Aspectos fisicos, químicos e tecnológicos do grão de milho. Circular Técnica 75. Sete Lagoas: Embrapa Milho e Sorgo, p.1-6.

PARENTONI, SN; GAMA, EEG; MAGNAVACA, R; REIFSCHSNEIDER, FJB; VILLASBOAS, GL. 1990. Milho doce. Informe Agropecuário, 14: 17-22.

PAUL, EA; CLARK, FE. 1996. Dynamics of residue decomposition and soil organic matter turnover. In: PAUL, EA; CLARK FE (eds). Soil microbiology and biochemistry Academic, p.158-179.

PEDROTTI, A; SILVA, TO; ARAÚJO, EM; ARAÚJO FILHO, RN; HOLANDA, FSR. 2015. Atributos químicos do solo modificados por diferentes sistemas de cultivo associados a culturas antecessoras ao cultivo do milho, nos Tabuleiros Costeiros. Magistra 27: 292-305.

PEREIRA FILHO, IA; CRUZ, JC. 2002. Cultivares de milho para o consumo verde. Sete Lagoas: Embrapa Milho e Sorgo, Circular técnica 15.

PEREIRA FILHO, IA; CRUZ, JC; SILVA, AR; COSTA, RV; CRUZ, I. 2018. Milho verde. Brasília: Embrapa Informação Tecnológica. Available https://www. agencia.cnptia.embrapa.br/gestor/milho/ arvore000fy 779 fnk02wx5ok0pvo4k3c1v9rbg. html. Accessed November 21, 2019.

PINHO, L; PAES, MCD; ALMEIDA, AC; COSTA, CA. 2008. Qualidade de milho verde cultivado em sistemas de produção orgânico e convencional. Revista Brasileira de Milho e Sorgo 7: 279-290.

PINHO, RG; CARVALHO, GS; RODRIGUES, VDN; PEREIRA, J. 2003. Características físicas e químicas de cultivares de milho para produção de minimilho. Ciência e Agrotecnologia 27: 1419-1425.

SANTOS, HG; JACOMINE, PKT; ANJOS, LHC; OLIVEIRA, VA; LUMBRERAS, JF; COELHO, MR; ALMEIDA, JA; CUNHA, TJF; OLIVEIRA, JB. 2018. Sistema brasileiro de classificação de solos. $5^{\mathrm{a}}$. ed. rev. e ampl. Brasília: Embrapa, 356p.

SANTOS, PF; WHILFORD, WG. 1981. The effects of microarthropods on litter decomposition in a chihuazhuan ecosystem. Ecology 62: 654-669.

SORATTO, RP; CRUSCIOL, CAC; COSTA, CHM; FERRARI NETO, J; CASTRO, GSA. 2012. Produção, decomposição e ciclagem de nutrientes em resíduos de crotalária e milheto, cultivados solteiros e consorciados. Pesquisa Agropecuária Brasileira 47: 1462-1470.

SOUZA, RS; VIDIGAL FILHO, OS; SCAPIM, CA; MARQUES, OJ; QUEIROZ, DC; OKUMURA, RS; RECHE, DL; CORTINOVE, VB. 2013. Produtividade e qualidade do milho doce em diferentes populações de plantas. Semina: Ciências Agrárias 34: 995-1010.

THOMAS, RJ; ASAKAWA, NM. 1993. Decomposition of leaf litter from tropical forage grasses and legumes. Soil Biology and Biochemistry 25: 1351-1361.

TORRES, JLR; CIABOTTI, ED; GOMES, FRC; LEAL JUNIOR, ALB; VIEIRA, DMS; COSTA, LL. 2017. Physico-chemical attributes of no-till Brassica crops cultivated after various cover crops. Horticultura Brasileira 35: 252-257.

TORRES, JLR; MAZETTO JÚNIOR, JC; SILVA JÚNIOR, J; VIEIRA, DMS; SOUZA, ZM; ASSIS, RL; LEMES, EM. 2019. Soil physical attributes and organic matter accumulation under no-tillage systems in the Cerrado. Soil Research 57: 712-718.

TORRES, JLR; PEREIRA, MG; CUNHA, MA; VIEIRA, DMS; RODRIGUES, ES. 2014. Produtividade do milho cultivado em sucessão a crotalária, milheto e braquiária no cerrado mineiro. Enciclopédia Biosfera 18: 2482-2491.

TORRES, JLR; PEREIRA, MG; FABIAN, AJ. 2008. Produção de fitomassa por plantas de cobertura e mineralização de seus resíduos em plantio direto. Pesquisa Agropecuária Brasileira 43: 421-428. 